AGNIESZKA ROMANKO

Wydział Prawa, Prawa Kanonicznego i Administracji

Katolickiego Uniwersytetu Lubelskiego Jana Pawła II

\title{
REFORMA URZĘDU INFORMACJI FINANSOWEJ I INSTYTUTU DZIEŁ RELIGIJNYCH
}

Treść: Wstęp. - 1. Instytucje wspierające w reformie Stolicy Apostolskiej i Państwa-Miasta Watykan. - 1.1. Rada Kardynałów. - 1.2. Papieska Komisja Referująca przy Instytucie Dzieł Religijnych. - 1.3. Papieska Komisja Referująca ds. organizacji struktur ekonomiczno-administracyjnych Stolicy Apostolskiej. - 2. Reforma Urzędu Informacji Finansowej. - 2.1. Utworzenie Komitetu Bezpieczeństwa Finansowego. - 2.1.1. Zadania. 2.1.2. Struktura i posiedzenia. - 2.2. Nowy Statut Urzędu Informacji Finansowej. - 2.2.1. Charakter i zadania. - 2.2.2. Struktura. - 2.2.3. Dostęp do informacji i współpraca na szczeblu krajowym i międzynarodowym. 3. Reforma Instytutu Dzieł Religijnych. - 3.1. Nadzór Urzędu Informacji Finansowej. - 3.2. Opracowanie propozycji reformy. - 3.2.1. Potwierdzenie misji Instytutu Dzieł Religijnych. - 3.2.2. Nowy program gospodarczy dla Instytutu Dzieł Religijnych. - 3.3. Modyfikacja Statutu Instytutu Dzieł Religijnych. - Zakończenie.

\section{Wstęp}

Na początku swojego pontyfikatu papież Franciszek zapowiedział przeprowadzenie reformy w Stolicy Apostolskiej i w Państwie-Mieście Watykan. Dlatego też utworzył specjalne podmioty odpowiedzialne za zbieranie informacji oraz przedstawianie swoich uwag i wniosków w zakresie przeprowadzenia zmian.

Celem artykułu jest próba ukazania dotychczas dokonanej reformy dwóch organów funkcjonujących w Stolicy Apostolskiej i Watykanie, tj. Urzędu Informacji Finansowej i Instytutu Dzieł Religijnych. W pierwszej 
kolejności zostaną opisane trzy instytucje wspierające papieża w zapowiedzianej reformie, tj. Rada Kardynałów, Papieska Komisja Referująca przy Instytucie Dzieł Religijnych i Papieska Komisja Referująca ds. organizacji struktur ekonomiczno-administracyjnych Stolicy Apostolskiej. Następnie będą scharakteryzowane zmiany przeprowadzone w Urzędzie Informacji Finansowej i Instytucie Dzieł Religijnych. Przede wszystkim analizie zostaną poddane następujące zagadnienia: utworzenie Komitetu Bezpieczeństwa Finansowego, zatwierdzenie nowego statutu Urzędu, analiza wybranych kompetencji Urzędu i Instytutu w najnowszym ustawodawstwie watykańskim i międzynarodowym, a także modyfikacja Statutu Instytutu Dzieł Religijnych.

\section{Instytucje wspierające w reformie Stolicy Apostolskiej i Państwa-Miasta Watykan}

W celu przeprowadzenia reformy w Stolicy Apostolskiej i Państwie-Mieście Watykan, papież Franciszek utworzył Radę Kardynałów oraz powołał dwie Komisje, tj. Papieską Komisję Referującą przy Instytucie Dzieł Religijnych i Papieską Komisję Referującą ds. organizacji struktur ekonomiczno-administracyjnych Stolicy Apostolskiej.

\subsection{Rada Kardynałów}

Dnia 13 kwietnia 2013 r. ${ }^{1}$, tj. miesiąc po wyborze na Stolicę Piotrową, papież zapowiedział utworzenie grupy kardynałów, której zadaniem będzie wspieranie go w zarządzaniu Kościołem powszechnym i opracowanie projektu rewizji konstytucji apostolskiej Pastor Bonus o Kurii Rzymskiej². Swoją decyzję umotywował sugestiami wyrażanymi podczas kongregacji generalnych poprzedzających

\footnotetext{
${ }^{1}$ Komunikat Sekretariatu Stanu z 13 kwietnia 2013 r., L'Osservatore Romano (wyd. pol.), 6 (2013), s. 62.

${ }^{2}$ Ioannes Paulus PP. II, Constitutio apostolica de Romana Curia Pastor Bonus (28.06.1988), AAS 80 (1988), s. 841-912; tekst polski w: Ustrój hierarchiczny Kościoła. Wybór źródeł, red. i oprac. W. Kacprzyk, M. Sitarz, Wydawnictwo KUL, Lublin 2006 [dalej cyt.: UHK], s. 217-257.
} 
konklawe ${ }^{3}$. Następnie, chirografem z dnia 28 września 2013 r. ${ }^{4}$, Ojciec Święty utworzył Radę Kardynałów (łac. Consilium Cardinalium). Podkreślił, że będzie mógł konsultować się zarówno z samą Radą, jak i z jej poszczególnymi członkami w sposób indywidualny ${ }^{5}$. W skład Rady pierwotnie wchodziło 8 kardynałów reprezentujących Północną i Południową Amerykę, Azję, Europę, Afrykę i Australię ${ }^{6}$. W celu osiągnięcia lepszej skuteczności działań podejmowanych przez tę instytucję, Biskup Rzymu dodał, że jej skład w przyszłości może ulec zmianie ${ }^{7}$. Obecnie Rada składa się z 9 członków $^{8}$.

${ }^{3}$ Zgodnie z Konstytucją apostolską Universi Dominici Gregis w Kongregacjach Kardynałów generalnych (łac. Cardinalium Congregationes generales) uczestniczą wszyscy kardynałowie, którzy nie mają prawowitej przeszkody, gdy tylko zostaną poinformowani o wakacie Stolicy Apostolskiej. Zob. IoAnnes PaUlus PP. II, Constitutio apostolica de Sede Apostolica vacante deque Romani Pontificis electione Universi Dominici Gregis (22.02.1996), AAS 88 (1996), s. 305-343; tekst polski w: UHK, s. 258-285, nr 7.

${ }^{4}$ Franciscus PP., Chirographum quo instituitur Consilium Cardinalium ad adiuvandum Romanum Pontificem in Universali Ecclesia gubernanda adque suscipiendum consilium emendationis Constitutionis Apostolicae «Pastor Bonus» de Curia Romana (28.09.2013), AAS 105 (2013), s. 875-876.

${ }^{5}$ Tamże, s. 876.

${ }^{6}$ Dnia 13 kwietnia 2013 r. papież Franciszek podał nazwiska ośmiu kardynałów wchodzących w skład tego organu: Giuseppe Bertello, przewodniczący Gubernatoratu Państwa Watykańskiego; Francisco Javier Errázuriz Ossa, arcybiskup senior Santiago de Chile (Chile); Oswald Gracias, arcybiskup Bombaju (Indie); Reinhard Marx, arcybiskup Monachium i Fryzyngi (Niemcy); Laurent Monsengwo Pasinya, arcybiskup Kinszasy (Demokratyczna Republika Konga); Sean Patrick O’Malley, kapucyn, arcybiskup Bostonu (Stany Zjednoczone Ameryki); George Pell, arcybiskup Sydney (Australia); Oscar Andrés Rodríguez Maradiaga, salezjanin, arcybiskup Tegucigalpy (Honduraz) - koordynator; bp Marcello Semeraro, ordynariusz Albano - sekretarz, nie wchodzi w skład rady. Zob. Komunikat Sekretariatu Stanu z 13 kwietnia 2013 r., s. 62.

${ }^{7}$ Franciscus PP., Chirographum quo instituitur Consilium Cardinalium, s. 876.

${ }^{8}$ Dnia 2 lipca 2014 r. papież Franciszek do grona Rady Kardynałów powołał dziewiątego członka, Kardynała Sekretarza Stanu, Pietro Parolin. Informacja na ten temat znajduje się w elektronicznym serwisie informacyjnym Biura Prasowego Stolicy Apostolskiej. Zob. Meeting of the Council of Cardinals, 2.07.2014, w: http:// 
Organ ustanowiony przez papieża Franciszka ma charakter doradczy, ponieważ jednym z jego zadań jest doradzanie Biskupowi Rzymu w zarządzaniu Kościołem powszechnym. Nie jest to „grupa mająca podejmować decyzje" . Posiedzenia Rady zwoływane są średnio co dwa miesiące. Rada odbyła już w sumie 14 posiedzeń ${ }^{10}$.

\subsection{Papieska Komisja Referująca przy Instytucie Dzieł Religijnych}

Papież Franciszek 24 czerwca 2013 r., w związku z koniecznością przeprowadzenia reform w instytucjach wspierających Stolicę Apostolską, aby „działalność ekonomiczna i finansowa była przesiąknięta zasadami Ewangelii”, ustanowił Papieską Komisję Referującą przy Instytucie Dzieł Religijnych ${ }^{11}$. Zadaniem Komisji jest zbieranie szczegółowych informacji o stanie prawnym i wszelkiej działalności Instytutu w celu umożliwienia jego lepszej harmonizacji z powszechną misją Stolicy Apostolskiej (CIOR, wstęp).

Komisja składa się z przynajmniej pięciu członków, w tym z Przewodniczącego, Koordynatora i Sekretarza. Przewodniczący jest prawnym przedstawicielem Komisji, a więc reprezentuje tę instytucję na zewnątrz. Koordynator - wyposażony w uprawnienia

visnews-en.blogspot.com/2014/07/meeting-of-council-of-cardinals.html [dostęp: 1.05.2016].

${ }^{9}$ W ten sposób określił Radę Kardynałów abp Angelo Becciu, Substytut do Spraw Ogólnych kierujący Pierwszą Sekcją Sekretariatu Stanu. Zob. Interview with H.E. Msgr. Angelo Becciu Substitute for General Affairs for L'Osservatore Romano: The Reform of Pope Francis (1.05.2013), w: http:/www.vatican.va/roman_curia/ secretariat_state/2013/documents/rc_seg-st_20130501_intervista-becciu_en.html [dostęp: 22.03.2016].

${ }^{10} 1-3.10 .2013$; 2-5.12.2013; 17-18.02.2014; 28-30.04.2014; 1-4.07.2014; 15-17.09.2014; 9-11.12.2014; 9-11.02.2015; 13-15.04.2015; 8-10.06.2015; 14-16.09.2015; 10-12.12.2015; 8-9.02.2016; 11-13.04.2016. Zob. elektroniczny serwis informacyjny Biura Prasowego Stolicy Apostolskiej, http://www.visnews-en.blogspot.com/ [dostęp: 1.05.2016].

${ }^{11}$ Franciscus PP., Chirographum quo constituitur Commissio circa Institutum pro Operibus Religionis (24.06.2013), AAS 105 (2013), s. 635-636 [dalej cyt.: CIOR]; tekst polski w: Ustrój hierarchiczny Kościoła. Wybór źródeł 2, red. i oprac. M. Sitarz, A. Romanko, U. Wasilewicz, P. Zając, TN KUL, Lublin 2013 [dalej cyt.: UHK 2], s. 307-309. 
pełnomocnika - działa na rzecz i w imieniu Komisji, zbiera dokumenty, dane i potrzebne informacje. Sekretarz świadczy pomoc pozostałym oraz przechowuje wszelkie dokumenty (CIOR 1). Komisja może współpracować zarówno z organami Instytutu Dzieł Religijnych, z pracownikami Kurii Rzymskiej, instytucjami związanymi ze Stolicą Apostolską i Państwem-Miastem Watykańskim, jak i innymi podmiotami (CIOR 5). Powinna na bieżąco informować Biskupa Rzymu o swojej działalności (CIOR 6), natomiast na zakończenie przedłożyć wyniki pracy, jak również zawartość archiwum (CIOR 7). Papież Franciszek stwierdził, iż rozwiązanie Papieskiej Komisji Referującej przy Instytucie Dzieł Religijnych „będzie ogłoszone” (CIOR 9). Należy postawić pytanie: czy Komisja przestanie wypełniać swoje zadania po osiągnięciu celu, dla realizacji którego została powołana, w szczególności dla „lepszej harmonizacji [...] Instytutu z powszechną misją Stolicy Apostolskiej” (CIOR, wstęp), czy też będzie kontynuowała wypełnianie powierzonych jej zadań?

\subsection{Papieska Komisja Referująca ds. organizacji struktur ekonomiczno-administracyjnych Stolicy Apostolskiej}

Kontynuując wprowadzanie reform w instytucjach Stolicy Apostolskiej mających na celu „uproszczenie i racjonalizację istniejących struktur”, a także „bardziej rozważne planowanie działalności ekonomicznej wszystkich urzędów watykańskich”, Ojciec Święty ustanowił Papieską Komisję Referującą ds. organizacji struktur ekonomiczno-administracyjnych Stolicy Apostolskiej ${ }^{12}$. Do jej zadań należy zebranie szczegółowych informacji w kwestiach ekonomicznych dotyczących urzędów watykańskich oraz współpraca z Radą Kardynałów poprzez udzielanie konsultacji i opracowywanie strategicznych rozwiązań i ulepszeń, aby ograniczyć wydatki, ułatwić przejrzystość w nabywaniu dóbr i usług, udoskonalić administrowanie nieruchomościami i ruchomościami, a także roztropnie działać w dziedzinie

\footnotetext{
${ }^{12}$ Franciscus PP., Chirographum quo Pontificia Commissio pro ordinatione structurae oeconomicae-administrativae Sanctae Sedis instituitur (18.07.2013), AAS 105 (2013), s. 707-708 [dalej cyt.: COS]; tekst polski w: UHK 2, s. 311-313.
} 
finansów, zapewnić prawidłowe stosowanie zasad rachunkowości oraz zabezpieczyć opiekę lekarską i ubezpieczenia społeczne wszystkim uprawnionym (COS, wstęp). Zadnia instytucjonalne Komisji nie naruszają prawa w zakresie kompetencji zarządzania albo działalności urzędów, które powinny współpracować z Komisją (COS 3) ${ }^{13}$.

W skład Papieskiej Komisji wchodzi przynajmniej ośmiu członków, w tym Przewodniczący i Sekretarz Koordynujący, mianowanych przez Biskupa Rzymu (COS 1$)^{14}$. Osoby te powinny być ekspertami w kwestiach prawnych, ekonomicznych, finansowych i organizacyjnych (COS 2). Komisja na zakończenie swojej kadencji - która nie została określona w liście przez papieża Franciszka ${ }^{15}$ - przedkłada Biskupowi Rzymu wszystkie zgromadzone dokumenty wraz z archiwum cyfrowym (COS 4).

\section{Reforma Urzędu Informacji Finansowej}

Urząd Informacji Finansowej został ustanowiony przez papieża Benedykta XVI w liście apostolskim z 30 grudnia 2010 r. dotyczącym zapobiegania nielegalnej działalności $w$ dziedzinie finansowej i monetarnej

${ }^{13}$ Ojciec Święty, poza Radą Kardynałów (COS 8) oraz ekspertami i firmami konsultingowymi (COS 5), nie wskazał „urzędów, które są niezbędne do pełnej współpracy z Komisją (COS 3). Poprzez analogię do Papieskiej Komisji Referującej przy Instytucie Dzieł Religijnych można wnioskować, że w szczególności chodzi o organy Instytutu Dzieł Religijnych, pracowników Kurii Rzymskiej i innych instytucji związanych ze Stolicą Apostolską i Państwem-Miastem Watykańskim (por. CIOR 5).

${ }^{14}$ Papież Franciszek ustanawiając Papieską Komisję podał jej skład osobowy: Joseph F.X. Zahra, Mons. Lucio Angel Vallejo Balda, Jean-Baptiste de Franssu, Enrique Llano, Jochen Messemer, Francesca Immacolata Chaouqui, Jean Videlain-Sevestre, George Yeo. Zob. Franciscus PP., Chirographum quo Pontificia Commissio pro ordinatione, s. 708.

${ }^{15}$ W tej sytuacji, na mocy kan. 17 Kodeksu Prawa Kanonicznego z 1983 r. (Codex Iuris Canonici auctoritate Ioannis Pauli PP. II promulgatus (25.01.1983), AAS 75 (1983), pars II, s. 1-317; tekst polski w: Kodeks Prawa Kanonicznego, przekład polski zatwierdzony przez Konferencję Episkopatu, Pallottinum, Poznań 1984) można postulować, aby zastosowanie znalazł art. $5 \$ 1 \mathrm{~PB}$, zgodnie z którym członkowie dykasterii mianowani są na okres 5 lat. 
oraz zwalczania tych zjawisk ${ }^{16}$. Ojciec Święty Franciszek, kontynuując działania podjęte przez swojego Poprzednika, w motu proprio z 8 sierpnia 2013 r. w sprawie zapobiegania i przeciwdziałania praniu pieniędzy, finansowaniu terroryzmu $i$ upowszechnianiu broni masowego rażenia ${ }^{17}$ utworzył Komitet Bezpieczeństwa Finansowego przy Urzędzie Informacji Finansowej i zatwierdził jego statut ${ }^{18}$. Natomiast 15 listopada 2013 r. zatwierdził nowy statut Urzędu Informacji Finansowej ${ }^{19}$.

\footnotetext{
${ }^{16}$ Benedictus PP. XVI, Litterae apostolicae motu proprio datae per la prevenzione ed il contrasto delle attività illegali in campo finanziario e monetario (30.12.2010), AAS 103 (2011), s. 7-8; tekst polski w: UHK 2, s. 217-219. Papież zatwierdził dla Urzędu również statut. Zob. BenedICTUs PP. XVI, Statuto dell'Autorità di Informazione Finanziaria (AIF) (30.12.2010), AAS 103 (2011), s. 9-13. Postanowił, że Urząd Informacji Finansowej jest instytucją związaną ze Stolicą Apostolską zgodnie z art. 186 i 190-191 PB, ma kanoniczną publiczną osobowość prawną oraz watykańską osobowość państwową, a w ramach swoich działań zajmuje się dykasteriami Kurii Rzymskiej oraz wszystkimi organami i instytucjami podlegającymi Stolicy Apostolskiej, jeżeli wypełniają zadania przewidziane w art. 2 Ustawy dotyczącej zapobiegania wprowadzaniu do obiegu środków pochodzących $z$ działalności przestępczej i finansowaniu terroryzmu oraz zwalczania tych zjawisk. Powyższa ustawa została zatwierdzona przez Benedykta XVI i promulgowana dnia 30 grudnia 2010 r. (N. CXXVII - Legge concernente la prevenzione ed il contrasto del riciclaggio dei proventi di attività criminose e del finanziamento del terrorismo (30.12.2010), AAS Suppl. 81 (2010), s. 167-201). Zob. także zmiany tej ustawy: N. CLXVI - Legge di conferma del Decreto del Presidente del Governatorato dello Stato della Città del Vaticano, N. CLIX, con il quale sono promulgate modifiche ed integrazioni alla Legge concernente la prevenzione ed il contrasto del riciclaggio dei proventi di attività criminose e del finanziamento del terrorismo del 30 dicembre 2010, N. CXXVII (24.04.2012), w: http://www.aif.va/ITA/pdf/Decreto_del_Presidente_del_ Governatorato_n_CLXVI\%20\%20ITA.pdf [dostęp: 28.05.2016]; N. CLXXXV - Legge recante modifiche al Decreto del Presidente del Governatorato del 25 gennaio 2012, N. CLIX, confermato in Legge del 24 aprile 2012, N. CLXVI (14.12.2012), w: http://www. aif.va/ITA/pdf/Legge_n_CLXXXV.pdf [dostęp: 28.05.2016].

${ }^{17}$ Franciscus PP., Litterae apostolicae motu proprio datae de vitandis pecunia sordide parta, nummariis rebus ad tromocratiam fovendam et accumulatione armorum ingentis destructionis (8.08.2013), AAS 105 (2013), s. 811-813 [dalej cyt.: VPS].

${ }_{18}$ Tenże, Statutum Comitatus de nummaria securitate (8.08.2013), AAS 105 (2013), s. 813-814 [dalej cyt.: Statutum Comitatus].

${ }^{19}$ Tenże, Litterae apostolicae motu proprio datae ad probandum novum statutum auctoritatis de communicatione nummaria (15.11.2013), AAS 105 (2013), s. 1138-1144
} 


\subsection{Utworzenie Komitetu Bezpieczeństwa Finansowego}

Stolica Apostolska - zgodnie z jej naturą i misją - uczestniczy w wysiłkach społeczności międzynarodowej mającej na celu ochronę i promowanie integralności, niezmienności i przejrzystości ekonomicznych i finansowych sektorów, a także zwalczanie nielegalnej działalności (VPS, wstęp). Dykasterie Kurii Rzymskiej oraz inne instytucje i podmioty zależne od Stolicy Apostolskiej, a także organizacje non-profit, które cieszą się osobowością prawną w prawie kanonicznym i mają siedzibę w Państwie Watykańskim, są zobowiązane do przestrzegania prawa Państwa-Miasta Watykan w dziedzinie: 1) środków w celu zapobiegania i prania brudnych pieniędzy oraz finansowania terroryzmu, 2) środków przeciwko tym, którzy zagrażają pokojowi i bezpieczeństwu międzynarodowemu oraz 3) nadzoru nad podmiotami prowadzącymi profesjonalną działalność finansową (VPS 1). Jurysdykcję w tych sprawach sprawują właściwe organy sądowe Państwa-Miasta Watykan, także w odniesieniu do dykasterii Kurii Rzymskiej, instytucji i podmiotów zależnych od Stolicy Apostolskiej oraz organizacji non-profit (VPS 3).

Zadania Komitetu Bezpieczeństwa Finansowego, jego strukturę i posiedzenia reguluje statut zatwierdzony przez papieża Franciszka w dniu 8 sierpnia $2013 \mathrm{r}$.

\subsubsection{Zadania}

Podstawowym zadaniem Komitetu Bezpieczeństwa Finansowego jest koordynacja kompetentnych instytucji Stolicy Apostolskiej i Państwa-Miasta Watykan w dziedzinie zapobiegania i przeciwdziałania praniu pieniędzy, finansowaniu terroryzmu i upowszechnianiu broni masowego rażenia (VPS 4).

Komitet Bezpieczeństwa Finansowego ustanawia kryteria i procedury służące do oceny ryzyka związanego z praniem brudnych pieniędzy, finansowaniem terroryzmu i upowszechnianiem broni masowego rażenia; zatwierdza i aktualizuje ogólną ocenę ryzyka; określa środki niezbędne do zarządzania i kontroli ryzyka; koordynuje

[dalej cyt.: Statutum Auctoritatis]. 
przyjmowanie i regularną aktualizację polityki i procedur związanych $\mathrm{z}$ praniem brudnych pieniędzy, finansowaniem terroryzmu i upowszechnianiem broni masowego rażenia; promuje aktywną współpracę i wymianę informacji między kompetentnymi organami Stolicy Apostolskiej i Państwa-Miasta Watykan; zapewnia zainteresowanym instytucjom odpowiednie informacje w zakresie zidentyfikowanego ryzyka; ustanawia procedurę i wewnętrzne wytyczne; prosi o informacje władze i podmioty działające w Stolicy Apostolskiej i Państwie-Mieście Watykan; zwraca się o badania i rady do ekspertów zewnętrznych (Statutum Comitatus, art. 2).

\subsubsection{Struktura i posiedzenia}

W skład Komitetu Bezpieczeństwa Finansowego wchodzą: Asesor do Spraw Ogólnych Sekretariatu Stanu (przewodniczący), Podsekretarz ds. Relacji z Państwami, Sekretarz Prefektury Spraw Ekonomicznych, Wice-sekretarz Generalny Gubernatoratu, Promotor Sprawiedliwości przy Trybunale Państwa Watykańskiego, Dyrektor Urzędu Informacji Finansowej (sekretarz) oraz Dyrektor Służb Bezpieczeństwa i Obrony Cywilnej Gubernatoratu (Statutum Comitatus, art. 1).

Przewodniczący, a w razie jego nieobecności Podsekretarz ds. Relacji z Państwami, zwołuje Komitet Bezpieczeństwa Finansowego raz na cztery miesiące, a także wówczas, gdy uzna to za konieczne. Przewodniczący ustala porządek obrad, koordynuje prace i czuwa nad tym, aby wszelkie informacje dotyczące przedmiotu obrad zostały przekazane członkom Komitetu. Zawiadomienie o porządku obrad powinno zostać przesłane 4 dni przed datą posiedzenia, a w sprawach pilnych co najmniej na 1 dzień przed spotkaniem za pomocą faxu, drogą elektroniczną albo innych sposobów bezpośredniej komunikacji. Uchwały Komitetu Bezpieczeństwa Finansowego zapadają bezwzględną większością głosów jego członków. Przewodniczący może zaprosić do udziału w posiedzeniach Komitetu również innych ekspertów (Statutum Comitatus, art. 3). 


\subsection{Nowy Statut Urzędu Informacji Finansowej}

Papież Franciszek we wstępie listu apostolskiego, którym zreformował Statut zatwierdzony przez papieża Benedykta XVI stwierdził, że wpływ na reformę struktury Urzędu miały konsultacje z wcześniej ustanowioną Papieską Komisją Referującą przy Instytucie Dzieł Religijnych. Podkreślił, że zmodyfikowanie Urzędu Informacji Finansowej przyczyni się do bardziej skutecznego wypełniania jego zadań instytucjonalnych. Należy zauważyć, że impulsem do zmiany Statutu, a w konsekwencji dalszej reformy Urzędu Informacji Finansowej, była również ustawa o przejrzystości, nadzorze i wywiadzie finansowym z 8 października 2013 r. $^{20}$.

\subsubsection{Charakter i zadania}

Urząd Informacji Finansowej jest instytucją związaną ze Stolicą Apostolską zgodnie z art. $186 \mathrm{~PB}^{21}$. Posiada kanoniczną publiczną osobowość prawną i ma siedzibę w Państwie-Mieście Watykan (Statutum Auctoritatis, art. 1).

Instytucja, w sposób autonomiczny i niezależny, pełni następujące funkcje: 1) nadzór i regulacja podmiotów, które prowadzą w sposób

\footnotetext{
${ }^{20}$ N. XVIII - Legge di conferma del decreto N. XI del Presidente del Governatorato, recante norme in materia di trasparenza, vigilanza ed informazione finanziaria, dell's agosto 2013 (8.10.2013), w: http://www.aif.va/ITA/pdf/Legge_n_XVIII_20131008.pdf [dostęp: 28.05.2016]; A. SAR AIs, Nuova Governanze Finanziaria per la Santa Sede, Sicurezza e giustizia 4 (2014), s. 32-33.

${ }^{21}$ „Są pewne instytucje, stare lub nowo utworzone, które chociaż nie należą w sensie ścisłym do Kurii Rzymskiej, jednak świadczą konieczną lub pożyteczną posługę papieżowi, Kurii i Kościołowi powszechnemu, będąc w jakiś sposób związane ze Stolicą Świętą". Papież Benedykt XVI ustanawiając Urząd Informacji Finansowej wskazał również na art. 190 PB („Wszystkie wyliczone powyżej instytucje Kościoła rzymskiego rządzą się własnymi prawa konstytucyjnymi i administracyjnymi”) i 191 PB („Do nowszych instytucji, chociaż wzorowanych częściowo na wcześniejszych przykładach, zaliczamy: Drukarnię Watykańską, Watykańską Księgarnię Wydawniczą, dzienniki, tygodniki, miesięczniki, wśród których wyróżnia się L'Osservatore Romano, Radio Watykańskie i Watykański Ośrodek Telewizyjny. Wszystkie te instytucje podlegają Sekretariatowi Stanu albo innym urzędom Kurii Rzymskiej, zgodnie z własnym prawem”).
} 
profesjonalny działalność finansową ${ }^{22}$; 2) nadzór i regulacja w celu zapobiegania i zwalczania prania brudnych pieniędzy i finansowania terroryzmu i 3) informacja finansowa (Statutum Auctoritatis, art. 2).

\subsubsection{Struktura}

Organami Urzędu Informacji Finansowej są: Przewodniczący, Rada Nadzorcza i Dyrektor. Urząd ma również 2 departamenty Nadzoru i Regulacji oraz Informacji Finansowej (Statutum Auctoritatis, art. 3).

W skład Rady Nadzorczej wchodzi 4 członków i Przewodniczący, którzy są mianowani przez Biskupa Rzymu na 5-letnią kadencję spośród osób cieszących się sprawdzoną wiarygodnością, niepozostających w jakichkolwiek konfliktach interesów i posiadających kompetencje w kwestiach prawnych, ekonomicznych i finansowych, a także w dziedzinie działalności Urzędu (Statutum Auctoritatis, art. 4 ust. 1). Rada Nadzorcza m.in. ustala ogólną politykę Urzędu i jej podstawowe strategie, przyjmuje regulacje wewnętrzne Urzędu, czy też nakłada sankcje administracyjne w sprawach przewidzianych przez prawo (Statutum Auctoritatis, art. 4 ust. 2). Przewodniczący kieruje Radą Nadzorczą, jest prawnym przedstawicielem Urzędu (Statutum Auctoritatis, art. 4 ust. 3). Zwołuje posiedzenia Rady Nadzorczej z reguły co trzy miesiące (Statutum Auctoritatis, art. 5 ust. 1). Do ważności posiedzenia powinno być obecnych przynajmniej trzech członków Rady (Statutum Auctoritatis, art. 5 ust. 5). Decyzje podjęte przez Radę Nadzorczą wymagają zwykłej większości głosów (Statutum Auctoritatis, art. 5 ust. 6).

Dyrektor Urzędu Informacji Finansowej jest mianowany przez Sekretarza Stanu na 5-letnią kadencję i powinien spełniać te same wymogi, które przewidziane są dla członków Rady Nadzorczej (Statutum Auctoritatis, art. 6 ust 1). Zgodnie z kierunkiem ogólnej polityki

\footnotetext{
${ }^{22}$ Papież Franciszek w motu proprio, w którym utworzył Komitet Bezpieczeństwa Finansowego, odnosząc się do Urzędu Informacji Finansowej, również wskazał, że Urząd Informacji Finansowej ma znaczące zadania w zakresie nadzoru i regulacji podmiotów profesjonalnie związanych z działalnością finansową (VPS 2).
} 
określonym przez Radę Nadzorczą, Dyrektor m.in. kieruje, organizuje i kontroluje działalność Urzędu, nadzoruje pracowników i dba o ich nieustanne szkolenia i podnoszenie kwalifikacji zawodowych, występuje z wnioskiem do Rady Nadzorczej o nałożenie sankcji administracyjnych w sprawach przewidzianych przez prawo (Statutum Auctoritatis, art. 6 ust. 2). Wspomagany jest przez Wice-dyrektora mianowanego - na wniosek Przewodniczącego - przez Sekretarza Stanu na 5-letnią kadencję (Statutum Auctoritatis, art. 6 ust. 3) ${ }^{23}$.

\subsubsection{Dostęp do informacji i współpraca na szczeblu krajowym} i międzynarodowym

Urząd Informacji Finansowej powinien mieć dostęp do dokumentów, wszelkich danych i informacji, a także powinien współpracować na szczeblu krajowym i międzynarodowym w sprawach przewidzianych przez prawo (Statutum Auctoritatis, art. 8). Dokumenty moga być używane wyłącznie dla celów przewidzianych w prawie, powinny zostać zabezpieczone tak, aby zapewnić ich nienaruszalność i poufność (Statutum Auctoritatis, art. 9).

\section{Reforma Instytutu Dzieł Religijnych}

Instytut Dzieł Religijnych (wł. Instituto per le Opere di Religione) ${ }^{24}$ podlega ustawodawstwu Stolicy Apostolskiej i Państwa-Miasta Watykan $^{25}$. Nazwa, cele, zadania i struktura IOR zostały uregulowane

${ }^{23}$ W zakresie mianowania i zatrudniania Dyrektora i Wice-dyrektora należy stosować Regulamin dotyczący personelu świeckiego zarządzającego w Stolicy Apostolskiej i Państwie Watykańskim (art. 6 ust. 5 Statutu). Zob. Benedictus PP. XVI, Regolamento per il personale dirigente laico della Santa Sede e dello Stato della Città del Vaticano (22.10.2012), „Bollettino ULSA” 20 (2012), w: http://www.ulsa. $\mathrm{va} /$ content/ulsa/it/pubblicazioni/bollettini/Bollettino_20_2012/atti-di-sua-santita-benedetto-xvi/regolamento-per-il-personale-dirigente-laico-della-santa-sede-e-. html [dostęp: 1.05.2016].

${ }^{24} \mathrm{~W}$ dokumentach źródłowych, jak i w literaturze, na określenie Instytutu Dzieł Religijnych używa się skrótu: IOR.

${ }^{25}$ Zgodnie $\mathrm{z}$ art. 1 ust. 1 Ustawy o źródłach prawa (N. LXXI - Legge sulle fonti del diritto (1.10.2008), AAS Suppl. 79 (2008), s. 65-70; tekst polski w: UHK 2, s. 153165.), pierwszym źródłem prawa i kryterium interpretacyjnym prawodawstwa 
w Statucie obowiązującym od 1 marca 1990 r. ${ }^{26}$ Papież Franciszek, potwierdzając znaczenie misji Instytutu dla dobra Kościoła katolickiego,

watykańskiego jest prawo kanoniczne. Ponadto do podstawowych źródeł prawa należą: Ustawa Zasadnicza Państwa-Miasta Watykan (zob. IoAnnes Paulus PP. II, Legge fondamentale dello Stato della Città del Vaticano (26.11.2000), AAS Suppl. Anno LXXI, N. 18, s. 75-83; tekst polski w: UHK, s. 302-309) i ustawy promulgowane dla Państwa-Miasta Watykan (zob. Ustawa o źródłach prawa, art. 1 ust. 2). Ponadto, zgodnie $\mathrm{z}$ art. 4 ust. 1 Ustawy o źródłach prawa, ustawodawstwo watykańskie jest zgodne $\mathrm{z}$ ogólnymi zasadami prawa międzynarodowego (np. SeCretaria Status, Conventio Monetalis Pactio inter Statum Civitatis Vaticanae et eius Opera inter Sanctam Sedem et Communitatem Europaeam. Convenzione Monetaria tra L'Uione Europea e lo Stato della Città del Vaticano (17.12.2009), AAS 102 (2010), s. 60-65; tekst polski w: UHK 2, s. 377-387) oraz z zasadami wynikającymi z traktatów i innych umów, których stroną jest Stolica Apostolska, z wyjątkiem art. 1 ust. 1 (np. Agreement between the Holy See, Acting Also in the Name and on Behalf of the Vatican City State, and the United States of America to Improve International Tax Compliance and to Implement the United States Foreign Account Tax Compliance Act (FATCA) (10.06.2015), w: http://www.state. gov/documents/organization/245238.pdf [dostęp: 1.05.2016]). Na mocy powyższego porozumienia, Instytut Dzieł Religijnych - od 10 czerwca 2015 r. - podlega ustawie o ujawnianiu informacji o rachunkach zagranicznych (FATCA), zgodnie z którą obywatele Stanów Zjednoczonych mieszkający poza granicami, zgłaszają swoje sprawozdania finansowe do International Revenue Service (IRS), który jest odpowiedzialny za pobór podatków oraz za stanowienie prawa podatkowego w Stanach Zjednoczonych. Zagraniczne instytucje finansowe zgłaszają do IRS informacje dotyczące rachunków amerykańskich obywateli przebywających poza granicami Stanów Zjednoczonych. Na mocy art. 1 ust. 1 lit. n) Porozumienia z 10 czerwca 2015 r., Instytut Dzieł Religijnych jest właśnie taką „sprawozdawczą” instytucją finansową dla Stolicy Apostolskiej i Państwa-Miasta Watykan.

${ }^{26}$ IoAnnes Paulus PP. II, Chirographum quo nova ordinatio datur Organismo «Istituto per le Opere di Religione» (1.03.1990), AAS 82 (1990), s. 1619-1629 (Statut IOR załączony został w formie aneksu do chirografu). Papież Jan Paweł II nadał Instytutowi nową strukturę, ale zachował jego dotychczasową nazwę i cel. IOR został utworzony przez papieża Piusa XII (PIus PP. XII, Chirographus in Civitate Vaticana Institutum Caritatis Religionisque Operibus Tutandis conditur (27.06.1942), AAS 34 (1942), s. 217-219). Do Instytutu została włączona Administracja Dzieł Religijnych (wł. Amministrazione per le Opere di Religione), której statut był zatwierdzony 17 marca 1941 r., a której nazwa pochodzi od ustanowionej 11 lutego 1887 r. przez papieża Leona XIII, Komisji Kardynałów dla Celów Charytatywnych (wł. Commissione Cardinaliza ad pias causa). 
Stolicy Apostolskiej i Państwa-Miasta Watykan, zatwierdził propozycje odnoszące się do „przyszłości IOR”27.

\subsection{Nadzór Urzędu Informacji Finansowej}

Instytut Dzieł Religijnych jest nadzorowany przez Urząd Informacji Finansowej. Pod tym względem, zarówno zadania Urzędu, jak i jego odpowiedzialność w zakresie wykonywania nadzoru IOR-u mającego na celu zapobieganie i zwalczanie nielegalnej działalności w dziedzinie finansowej, zostały doprecyzowane w Ustawie N. XVIII z 8 października 2013 r. Realizując Tytuł III Ustawy, Urząd Informacji Finansowej wydał Rozporządzenie pt. „Nadzór ostrożnościowy podmiotów prowadzących zawodową działalność finansową"28. Rozporządzenie określa kryteria dotyczące organizacji i zarządzania podmiotami prowadzącymi działalność finansową na zasadach działalności zawodowej - w tym również Instytut Dzieł Religijnych - wyznaczając m.in. ich strukturę, organizację funkcji administracyjnych, sposób kontroli wewnętrznej oraz zasady i procedury zarządzania ${ }^{29}$.

\subsection{Opracowanie propozycji reformy}

Powołane przez papieża Franciszka Papieskie Komisje mające na celu przeprowadzenia reformy w Stolicy Apostolskiej i Państwie-Mieście Watykan, przedstawiły wyniki swojej pracy, wskazując na dalszą potrzebę zmian.

${ }^{27}$ Communique: Holy Father approves recommendations on the future of the IOR Bollettino Sala Stampa della Santa Sede N. 0244, 7.04.2014, w: https://press.vatican. $\mathrm{va/content/salastampa/it/bollettino/pubblico/2014/04/07/0244/00548.html} \mathrm{[dostęp:}$ 28.05.2016].

${ }^{28}$ Financial Information Authority, Regulation no. 1 on Prudential Supervision of the Entities Carrying out Financial Activities on a Professional Basis. Implementing Title III of the Law Introducing Norms on Transparency, Supervision and Financial Intelligence, No. XVIII of 8 October 2013 (25.09.2014), Vatican City State 2014, w: http://www.aif.va/ENG/pdf/Regolamenti/AIF_Regulation1_Prudential_Supervision.pdf [dostęp: 28.05.2016].

${ }^{29}$ Legal Framework, w: http://www.ior.va/content/ior/en/aml-cft-policy/aml-cft-policy-contenuto.html [dostęp: 28.05.2016]. 


\subsubsection{Potwierdzenie misji Instytutu Dzieł Religijnych}

Biuro Prasowe Stolicy Apostolskiej w komunikacie z 7 kwietnia 2014 r. podało, że propozycje dotyczące przeprowadzenia reformy IOR, zostały opracowane wspólnie przez przedstawicieli Papieskiej Komisji Referującej przy Instytucie Dzieł Religijnych, Papieskiej Komisji Referującej ds. organizacji struktur ekonomiczno-administracyjnych Stolicy Apostolskiej, a także przez organy Instytutu Dzieł Religijnych, tj. Komisję Kardynałów (wł. la Commissione Cardinalizia; zob. Statut IOR, art. 5-8) i Radę Nadzorczą (wł. il Consiglio di Sovrintendenza; zob. Statut IOR, art. 10-17). Kardynał Prefekt Sekretariatu ds. Gospodarczych ${ }^{30}$, po uzyskaniu zgody Przewodniczącego Komisji Kardynałów przy Instytucie, przedłożył opracowane propozycje papieżowi. Projekt został sporządzony na podstawie informacji dotyczących statusu prawnego IOR i danych zebranych przez Komisję Referującą przy Instytucie Dzieł Religijnych, które jeszcze w lutym 2014 r. zostały przedstawione Biskupowi Rzymu i Radzie Kardynałów. Zgodnie z zatwierdzonymi propozycjami, Instytut Dzieł Religijnych będzie kontynuował rozważną służbę względem Kościoła Katolickiego na całym świecie, zapewniając wyspecjalizowane usługi finansowe, a także pomagać Biskupowi Rzymu i instytucjom z nim współpracującym w jego misji w Kościele ${ }^{31}$.

\subsubsection{Nowy program gospodarczy dla Instytutu Dzieł Religijnych}

Dnia 9 lipca 2014 r. w Biurze Prasowym Stolicy Apostolskiej odbyła się konferencja prasowa, podczas której zaprezentowano nowy

\footnotetext{
${ }^{30}$ Sekretariat ds. Gospodarczych jest nową dykasterią Kurii Rzymskiej utworzoną 24 lutego 2014 r. wraz z Radą ds. Gospodarczych i urzędem Audytora Generalnego. Zob.: Franciscus PP., Litterae apostolicae motu proprio datae ad Novum Consilium instituendum pro Coordinatione Rerum Oeconomicarum ac Administratoriarum Sanctae Sedis Civitatisque Vaticanae Fidelis dispensator et prudens (24.02.2014), AAS 106 (2014), s. 164-165; Tenże, Statuti dei nuovi organismi economici (22.02.2015), Communicationes 47 (2015), s. 25-44.

${ }^{31}$ Communique: Holy Father approves recommendations on the future of the IOR.
} 
program gospodarczy dla Stolicy Apostolskiej ${ }^{32}$. Udział w niej wzięli: Kardynał Prefekt Sekretariatu ds. Gospodarczych, Wicekoordynator Rady ds. Gospodarczych i Przewodniczący Komisji Kardynałów przy Instytucie Dzieł Religijnych. Podkreślono, że celem podjętych inicjatyw jest ulepszenie zarządzania ekonomicznego i administracyjnego Stolicy Apostolskiej i Państwa-Miasta Watykan. Prezentowane zmiany są owocem szczegółowej analizy rekomendacji opracowanych przez Papieską Komisję Referującą ds. organizacji struktur ekonomiczno-administracyjnych Stolicy Apostolskiej i zostały zaaprobowane przez Radę ds. Gospodarczych i Radę Kardynałów.

Po zatwierdzeniu 7 kwietnia 2014 r. przez papieża Franciszka misji Instytutu Dzieł Religijnych, został opracowany plan, który będzie wdrożony wspólnie przez „nowe kierownictwo z zastosowaniem nowego typu zarządzania"33. W ciągu najbliższych trzech lat zostanie zmodernizowana działalność Instytutu i zmieniony jego Statut. Uczestnicy konferencji wskazali trzy strategiczne priorytety: 1) wzmocnienie podstaw biznesowych IOR-u; 2) stopniowe przeniesienie majątku Instytutu do mającej powstać centralnej struktury do Zarządzania Majątkiem Watykańskim (VAM) w celu niepowielania zadań przez instytucje watykańskie oraz 3) skoncentrowanie się Instytutu Dzieł Religijnych na udzielaniu opinii i usług finansowych dla pracowników Watykanu ${ }^{34}$.

\footnotetext{
${ }^{32}$ Zob. New Economic Framework for the Holy See, 9.07.2014, w: http://visnews-en. blogspot.com/2014/07/new-economic-framework-for-holy-see.html [dostęp: 28.05.2016]. Przedmiotem programu gospodarczego, poza Instytutem Dzieł Religijnych, były także: Administracja Patrimonium Stolicy Apostolskiej, Fundusz Emerytalny i media watykańskie.

${ }^{33}$ Reforma IOR-u i nowa struktura ekonomiczna Stolicy Apostolskiej, L'Osservatore Romano (wyd. pol.), 7 (2014), s. 60.

${ }^{34}$ New Economic Framework for the Holy See.
} 


\subsection{Modyfikacja Statutu Instytutu Dzieł Religijnych}

Dnia 10 stycznia 2015 r. w Statucie Instytutu Dzieł Religijnych zostały wprowadzone trzy zmiany ${ }^{35}$, które weszły w życie w dniu promulgacji powyższego dokumentu.

Pierwsza modyfikacja polega na zwiększeniu liczby członków Komisji Kardynałów ${ }^{36}$ i Rady Nadzorczej ${ }^{37}$ z pięciu do sześciu ${ }^{38}$. Należy zauważyć, że nie uległy zmianie pozostałe kwestie, takie jak np. nominacja członków przez Biskupa Rzymu ${ }^{39}$. Następnie podkreślono, że do ważności posiedzeń i uchwał podejmowanych przez Komisję

${ }^{35}$ Cardinalium Commissio ad Vigilandum Institutum Operum Religionis (I.O.R.), Rescriptum «ex Audientia SS.mi» (10.01.2015), AAS 107 (2015), s. 286 [dalej cyt.: Rescriptum IOR].

${ }^{36}$ Zgodnie z dotychczasową regulacją Statutu promulgowanego przez Jana Pawła II, Komisja Kardynałów składała się z 5 kardynałów mianowanych przez Biskupa Rzymu i przewodniczył jej kardynał wyznaczony przez pozostałych członków („La Commissione Cardinalizia è composta di cinque Cardinali nominati dal Santo Padre e presieduta dal Cardinale designato dai Membri della Commissione stessa”, Statut IOR, art. 5). Obecnie w skład Komisji Kardynałów wchodzą: card. Santos Abril y Castelló (przewodniczący), card. Thomas Christopher Collins, card. Pietro Parolin, card. Christoph Schönborn, card. Jean-Louis Tauran i card. Josip Bozanic. Zob. http://www.ior.va/content/ior/en/governance.html [dostęp: 28.05.2016].

${ }^{37}$ Rada Nadzorcza składała się z pięciu osób i jej członkowie byli powoływani przez Komisję Kardynałów spośród osób z doświadczeniem i sprawdzonej wiarygodności ekonomiczno-finansowej („Il Consiglio di Sovrintendenza è nominato dalla Commissione Cardinalizia ed è composto da cinque Membri di riconosciuta esperienza economico-finanziaria e di provata affidabilità", Statut IOR, art. 11). Trzeba zauważyć, że ze względu na nieukończenie procesu reformy IOR-u, na stronie internetowej Instytutu zamieszono jedynie czterech członków Rady Nadzorczej: Jean-Baptiste Douville de Franssu (przewodniczący), prof. Mary Ann Glendon, sir Michael Hintze i Mauricio Larraín. Zob. http://www.ior.va/content/ior/en/governance.html [dostęp: 28.05.2016].

38 „il numero dei Membri della Commissione Cardinalizia e del Consiglio di Sovrintendenza è elevato da cinque a sei”, Rescriptum IOR, s. 286.

${ }^{39}$ Zob. także: Press Release of the Istituto per le Opere di Religione (IOR), Rescriptum ex audientia Ss.mi on the modification to the IOR Statute (22.01.2015), w: http:// www.ior.va/content/dam/ior/documenti/ComunicatiStampaNotizie/2015/inglese/ Press\%20Release_IOR_Rescriptum_20150122_ENG(1).pdf [dostęp: 28.05.2016]. 
Kardynałów i Radę Nadzorczą, wymagana jest większość głosów ${ }^{40}$. Trzecia modyfikacja Statutu dotyczy uprawnienia Przewodniczącego Komisji Kardynałów w zakresie głosowania. Stwierdzono, że Przewodniczący głosuje wówczas, gdy zachodzi konieczność uzyskania większości wymaganej do utworzenia kolegium lub do podjęcia konkretnych decyzji, w których wymagana jest opinia trzech członków ${ }^{41}$.

\section{Zakończenie}

Z przeprowadzonych badań należy wyprowadzić następujące wnioski:

1. Papież Franciszek utworzył trzy instytucje wspomagające go w reformie Stolicy Apostolskiej i Państwa-Miasta Watykan: 1) Radę Kardynałów, której celem jest wspieranie Biskupa Rzymu w zarządzaniu Kościołem powszechnym i opracowanie projektu rewizji konstytucji apostolskiej Pastor Bonus o Kurii Rzymskiej; 2) Papieską Komisję Referującą przy Instytucie Dzieł Religijnych, której zadanie polega na gromadzeniu informacji o Instytucie i 3) Papieską Komisję Referującą ds. organizacji struktur ekonomiczno-administracyjnych Stolicy Apostolskiej, mającej zbierać informacje w zakresie spraw ekonomicznych dotyczących urzędów watykańskich.

2. Ojciec Święty Franciszek zatwierdził nowy Statut Urzędu Informacji Finansowej, którego podstawowym zadaniem jest nadzór i regulacja podmiotów prowadzących zawodową działalność finansową, w tym Instytutu Dzieł Religijnych. Ponadto utworzył Komitet Bezpieczeństwa Finansowego, który koordynuje odpowiednie instytucje Stolicy Apostolskiej i Państwa-Miasta

\footnotetext{
${ }^{40}$ „per la validità delle adunanze e delle deliberazioni della Commissione e del Consiglio è necessario il voto favorevole della maggioranza dei Membri in carica", Rescriptum IOR, s. 286.

41 „il Presidente della Commissione Cardinalizia ha voto di qualità sempre che sia necessario per formare la maggioranza richiesta per costituire il Collegio o per adottare delibere concrete nel cui caso sarà sempre necessario il parere coincidente di tre Membri”, Rescriptum IOR, s. 286.
} 
Watykan w dziedzinie zapobiegania i zwalczania nielegalnej działalności finansowej.

3. Misją Instytutu Dzieł Religijnych jest służba dla dobra Kościoła Katolickiego, Stolicy Apostolskiej i Państwa-Miasta Watykan. Zmiany w Instytucie ukierunkowane są na ulepszenie i uproszczenie w zakresie zarządzania ekonomicznego i administracyjnego Stolicy Apostolskiej oraz Państwa-Miasta Watykan.

4. Reforma zarówno Urzędu Informacji Finansowej, jak i Instytutu Dzieł Religijnych nie została jeszcze ukończona, co zostało podkreślone w dniu 9 lipca 2014 r. na konferencji w Biurze Prasowym Stolicy Apostolskiej, a także na stronie internetowej Instytutu Dzieł Religijnych. W kontekście dotychczasowych zmian, a także wypowiedzi członków Papieskich Komisji powołanych w celu przeprowadzenia reformy, należy spodziewać się dalszych modyfikacji w instytucjach Stolicy Apostolskiej i Państwa-Miasta Watykan.

\section{The Reform of the Financial Information Authority and the Institute for the Works of Religion}

The author analyzes the reform of the Pope Francis in the Holy See and Vatican City State. At the beginning the Pope Francis established three organs helping him in the reform: Council of Cardinals, Papal Commission for the Reference on the Institute for Works of Religion, Pontifical Commission for Reference on the Organisation of the Economic-Administrative Structure of the Holy See. Then the author describes the changes in the Financial Information Authority - establishment the Financial Security Committee and approving the new statute of the Authority - and in the Institute for the Works of Religion.

SŁowa Kluczowe: Rada Kardynałów, Papieska Komisja Referująca przy Instytucie Dzieł Religijnych; Papieska Komisja Referująca ds. organizacji struktur ekonomiczno-administracyjnych Stolicy Apostolskiej; Komitet Bezpieczeństwa Finansowego 
Key words: Council of Cardinals; Papal Commission for the Reference on the Institute for Works of Religion; Pontifical Commission for Reference on the Organization of the Economic-Administrative Structure of the Holy See; Financial Security Committee

Nota o Autorze:

Dr Agnieszka Romanko - asystent Katedry Kościelnego Prawa Publicznego i Konstytucyjnego, Instytut Prawa Kanonicznego Wydziału Prawa, Prawa Kanonicznego i Administracji Katolickiego Uniwersytetu Lubelskiego Jana Pawła II. 